\title{
ReAKTUALISASI Syari'aH Islam
}

\author{
Zaenul Mahmudi \\ Dosen Fakultas Syari'ah Universitas Islam Negeri (UIN) Malang
}

\begin{abstract}
As syari'ah, al-Qur'an is one of the sources of Islamic law and the living orientation for Muslim ummah in going through their life. Textual message of Islam (al-Qur'an) had stopped when Muhammad died. In other side, the growing up of the problems is faster than their solutions can be made. The problems grow up in line with globalization and information technology that offer some traditions and cultures that meet our different cultures and traditions. We can't create a new message of al-Qur'an but we can create methode of understanding to understand al-Qur'an in nowdays context. We need to use methodological tools from multidiscipline of science in understanding al-Qur'an in order to actualize spirit of al-Qur'an in Indonesian and nowdays context.
\end{abstract}

Keywords: syari'ah, reactualization, islamic jurisprudence

\section{A. Pendahuluan}

Dalam kehidupan sosial yang berubah, diskursus tentang reaktualisasi syari'ah telah sering diwacanakan sebagai upaya menselaraskan ajaran Islam dengan perubahan zaman dan perubahan sosial. Dalam konteks Indonesia, pada tahun 90-an, Munawir Sadzali telah mewacanakan "kontekstualisasi ajaran Islam" dalam konteks keindonesiaan, khususnya dalam permasalahan pembagian warisan (Sjadzali, 1995). Dia menilai pembagian warisan yang ada dalam ketentuan fikih klasik perlu ada penyesuaian dengan kultur Indonesia. Menurutnya perlu ada ketentuan yang lebih fleksibel dengan kondisi para ahli waris. Namun wacana ini hanya tinggal wacana, karena tidak ada dukungan dari masyarakat.

Tidak adanya respon masyarakat terhadap wacana yang mengangkat budayanya sendiri sebagai dasar pijakan hukum menunjukkan bahwa "budaya" yang berkembang di Indonesia masih didominasi pemikiran fikih 
yang dihasilkan oleh para ulama abad 8-10-an yang disokong penuh oleh tradisi pemikiran fikih pesantren. Masyarakat Indonesia belum memiliki keberanian dan merasa berat untuk meninggalkan pemikiran fikih yang dihasilkan oleh para ulama klasik. Padahal pemikiran tersebut merupakan pemikiran yang dihasilkan sebagai respon terhadap kondisi sosial pada waktu itu yang kemungkinan sudah tidak sesuai lagi dengan konteks keindonesiaan dan kekinian.

Dalam fikih, banyak teori yang memberikan ruang terjadinya perubahan hukum ketika kondisi sosial juga berubah. Kaidah fikih "al-hukm yadûru ma'a 'illatih urjûdan wa 'adaman" (hukum itu berubah berkesesuaian dengan ada dan tidaknya illah) dan "taghayyur al-ahkâm bi taghayyur alazminah wa al-amkinah wa al-ahwal" (perubahan hukum seiring dengan perubahan zaman, tempat, dan kondisi) ini memperkuat statemen tersebut. Di sisi lain, jargon yang mengatakan "al-Islâm shalih li kull zamân wa makân" (Islam itu baik untuk segala zaman dan tempat) menuntut agar ajaranajaran Islam, termasuk ketentuan hukum fikih senantiasa disesuaikan dengan tuntutan dan perubahan zaman. Oleh karena itu, pemikiran fikih sebagai hasil pemikiran manusia selalu berubah sesuai dengan perubahan zaman dan perubahan sosial.

Tulisan ini berusaha mencermati aspek-aspek syari'ah sebagai upaya untuk mengaktualisasikannya di masyarakat dalam konteks keindonesiaan dan kekinian yang telah mengalami perubahan besar dari kondisi ketika formulasi hukum fikih dilakukan oleh para ulama klasik.

\section{B. Kemutlakan Syari'ah dan Relativitas Fikih}

Syari'ah berasal dari bahasa Arab syarîah yang secara bahasa berarti sumber air atau tempat yang dilalui orang atau hewan untuk minum (Ibn Manzûr, t.th, 175). Syarîa merupakan sinonim dan berakar kata sama dengan syar' yaitu syara'a yang berarti mengundangkan (to enact laws) (Wehr, 1976: 465-466). Secara terminologis, syari'ah adalah apa yang dilegislasikan oleh Allah kepada para hamba-Nya yang meliputi hukum aqâ'idiyyah, 'amaliyyah dan khuluqiyyah (Ismâ'îl, 1985: 7). Syari'ah merupakan dasar-dasar, keyakinan-keyakinan, pokok-pokok, aturan-aturan 
politik, kemasyarakatan, ekonomi, pidana yang disyariatkan oleh Allah untuk mengatur kehidupan pribadi dan sosial di muka bumi sesuai dengan kehendak-Nya (Sânu, 2000, 249).

Maksud aturan-aturan syari'ah hanya diketahui oleh Allah karena Dialah yang membuat dan mengundangkannya. Manusia bisa memahami aturan-aturan tersebut, namun kebenaran pemahamannya hanya sampai pada tingkat kebenaran relatif. Seseorang tidak berhak mengklaim pemahamannya terhadap syari'ah sebagai kebenaran Tuhan yang bersifat mutlak, karena klaim ini akan mengeliminasi pemahaman orang lain yang berbeda dengan pemahamannya. Setiap pemahaman orang terhadap syari'ah mempunyai peluang benar dan salah tergantung kepada kualitas intelektual mereka.

Syari'ah para rasul mempunyai tujuan yang sama untuk menegakkan agama, keadilan, dan mengajarkan ketauhidan, namun dalam tataran aplikatif, syariat yang diberikan kepada para rasul berbeda-beda, disesuaikan dengan adat dan kebiasaan setempat ketika itu untuk membimbing para umatnya (al-Fâsi, T.th.: 20). Aturan-aturan syari'ah tersebut tidak melakukan eliminasi terhadap semua tradisi yang mengakar di masyarakat.

Apabila diperhatikan, maka di dalam syari'ah-syari'ah tersebut terdapat prinsip perkembangan (tathawwur) dari syari'ah pertama hingga syari'ah terakhir dan terdapat prinsip fleksibilitas (murûnah) yang akomodatif dengan kondisi sosial budaya. Terhadap adat kebiasaan, pada satu sisi, syari'ah berperan menjustifikasinya dengan prinsip syari'ah dan di sisi lain membatalkannya ketika adat kebiasaan tersebut bertentangan dengannya. Menurut Mohamed Taha, aturan-aturan syari'ah para nabi sebelum Muhammad mempunyai karakteristik yang berhadapan secara diametral. Syari'ahYahudi dan syari'ah Nasrani, masing-masing menduduki ekstrimitas yang berlawanan. Mohamed Taha mencontohkan:

\footnotetext{
"Kamu sudah mendengar perkataan demikian: "Mata ganti mata dan gigi ganti gigi. Tetapi Aku ini berkata kepadamu: "Jangan melawan orang yang jahat, melainkan barang siapa menampar pipi kananmu, berilah kepadanya pipi yang sebelah lagi" (Matius 5:38-39).
} 
Ketentuan yang pertama merupakan syari'ah Yahudi yang keras dan tegas, sementara ketentuan yang kedua merupakan Syari'ah Nasrani yang lunak, bahkan memberikan kesempatan kepada orang yang melakukan tindak kejahatan untuk melakukan kejahatan lagi (Taha, 1996: 121). Syari'ah Yahudi merupakan tesis, Syari'ah Nasrani menjadi antitesis, dan Syari'ah Islam sebagai sintesis antara kedua syari'ah tersebut (Cooper, 2000: 115). Syari'ah Islam mengakomodir kedua ketentuan tersebut; melakukan qishas merupakan kelaziman, namun yang lebih baik adalah memaafkan kesalahan orang lain, bukan membiarkan dia melakukan kejahatan lagi terhadap dirinya sebagaimana ketentuan syari'ah Nasrani (5: 45 dan 42: 40).

Selain sebagai penengah kedua ekstrimitas syari'ah, Syari'ah Islam merupakan penyempurna bagi syari'ah-syari'ah sebelumnya. Kesempurnaan syari'ah Islam terlihat dari karakteristiknya yang tidak dimiliki oleh syari'ahsyari'ah sebelumnya. Pertama, Syari'ah Islam bersifat universal dalam arti tidak dikhususkan untuk bangsa tertentu, tetapi untuk semua bangsa di dunia; kedua, tidak temporal yang hanya untuk masa tertentu saja dan ketiga, tidak terpengaruh dengan perubahan zaman karena Syari'ah Islam memuat prinsip-prinsip yang umum, sehingga nash-nashnya elastis dan fleksibel (alQaradlâwi, 2001: 25-27), sehingga tetap aktual sepanjang zaman.

Sementara fikih berasal dari kata figh yang menurut bahasa adalah al'ilm bi al-shay' wa al-fahm lah (mengetahui sesuatu dan memahaminya) (Ibn Manzûr, T.th (13): 522), to understand, to comprehend (memahami, mengetahui) (Wehr, 1976: 732), dan mengetahui perkara-perkara rahasia (idrak daqaiq al-umûr) (Qal'aji, 1985: 348). Sedangkan menurut istilah, fikih adalah mengetahui hukum-hukum shar' yang bersifat 'amaliyyah yang diselidiki dari dalil-dalil yang terperinci (Qal'aji, 1985: 348; Sânû, 2000: 323; Zahrah, T.th: 6; dan Khalâf, 1978: 11). Fikih merupakan hasil dari proses interpretasi terhadap Al-Qur'an dan Hadis yang dilakukan secara lambat dan gradual dengan memperhatikan kondisi sosial budaya yang berjalan seiring dengan Al-Qur'an dan Hadis.

Pemaknaan fikih secara terminologis di atas terlihat bahwa aspek human pada fikih membedakannya dengan Syari'ah yang dilegislasikan secara divine. Sisi humanitas fikih terletak pada posisi fikih sebagai hasil 
pemahaman manusia terhadap syariat yang tertuang dalam Al-Qur'an dan Hadis, sehingga kata-kata fikih dilekatkan dengan manusia biasa (bukan rasul), seperti fikih Hanafi, fikih Maliki, fikih Syafi'i, dan fikih Hanbali.

Fikih merupakan hasil pergulatan intelektual dan dialektika mereka dengan kondisi sosial ketika dan di mana mereka hidup. Di samping itu, hasil istinbatth fikih juga dipengaruhi oleh kualitas mujtahid yang melakukan istinbath hukum. Dalam istinbatth fikih terdapat peluang salah di dalamnya, seperti ketika ada beberapa mujtahid yang melakukan ijtihad terhadap permasalahan yang sama, namun menghasilkan ijtihad yang berbeda, walaupun kesalahan dalam berijtihad tersebut tidak diketahui (Weiss, 1998: 119-120). Dengan demikian, kebenaran yang dihasilkan oleh hasil ijtihad fikih merupakan kebenaran relatif, semua orang yang melakukan ijtihad dalam bidang fikih memiliki peluang kebenaran dan peluang kesalahan sekaligus.

\section{Ruang-Ruang Reaktualisasi}

Gambaran syari'ah Islam di atas menunjukkan bahwa dia tidak bersifat kaku terhadap tradisi dan perkembangan zaman. Syari'ah Islam selalu berdialektika dengan kondisi sosial budaya. Dalam melakukan dialektika ini, Syari'ah Islam mempunyai dua peran, yaitu sebagai model of reality yang mengadopsi budaya masyarakat dan sebagai model for reality (Tibi, 1991: 815) yang berperan melakukan formatisasi budaya yang diidealkan dengan mengubah kondisi sosial dan budaya yang telah ada. Formatisasi budaya ini tidak dilakukan secara langsung oleh Allah melalui $\mathrm{Al}$-Qur'an, tetapi melalui nalar manusia yang menafsirkan aturan-aturan Allah yang tertuang dalam Syari'ah Islam tersebut.

Salah satu peran dan merupakan peran utama diturunkannya syari'ah Islam adalah untuk melakukan transformasi sosial dan budaya masyarakat pada waktu itu. Tradisi dan budaya yang bertentangan dengan nilai-nilai moral dan prinsip-prinsip humanisme dieliminir dan digantikan dengan model yang mencerminkan nilai-nilai dan prinsip-prinsip tersebut. Peran ini harus tetap dijaga untuk meluruskan budaya-budaya dan tradisi-tradisi 
yang bertentangan dengan syari'ah Islam dan tidak mencerminkan prinsipprinsip universal yang diakui semua manusia.

Ada beberapa aspek Al-Qur'an yang perlu dikaji ulang untuk mendukung upaya reaktualisasi syari'ah Islam dalam konteks keindonesiaan dan kekinian, di antaranya adalah konsep qath'î dan zhannî, konsep makkiyyah dan madaniyyah, dan pembacaan baru terhadap Syari'ah.

\section{Konsep Qath'î dan Zhannî}

Dari sisi makna yang dimaksud (dalalah)nya, nash-nash Al-Qur'an ada yang qathî di mana makna nash tersebut sudah pasti, tidak memerlukan takwil, dan tidak menunjuk kepada makna yang lain dan ada yang zhannî di mana makna nash yang dimaksudkan tidak jelas, masih bisa ditakwilkan, dan mengandung berbagai makna. Para ulama fikih biasanya mengkategorikan nash-nash yang menunjukkan bilangan sebagai nash qath'î, sementara nash yang secara kebahasaan memiliki dua pengertian (musytarak) dan makna yang tidak jelas sebagai nash zhannî (Khalâf, 1978: 34-35).

Definisi yang cenderung tekstualis ini dapat menghilangkan watak dinamisitas Syari'ah Islam dalam mengakomodir permasalahan kekinian. Pemakanaan qath î dan zhannî perlu ada pembaruan; dari tekstual menuju kontekstual. Nash-nash qath'̂े, sebagai sesuatu yang tidak bisa ditakwilkan seharusnya adalah ayat-ayat $\mathrm{Al}$-Qur'an yang mengandung prinsipprinsip umum, dasar, dan universal yang diakui keberlakuannya sepanjang masa, sementara nash-nash zhannî, seharusnya adalah nash-nash yang maknanya tidak mencerminkan kepada prinsip-prinsip umum, dasar, dan universal. Oleh karena itu harus ditakwilkan ke arah yang mendekati prinsip-prinsi yang universal.

Ajaran-ajaran yang termasuk nash qathî adalah ajaran tentang kebebasan dan pertanggungjawaban individu (99: 7-8), kesetaraan manusia di hadapan Allah (49: 13), keadilan (5: 8 dan 16: 90), persamaan manusia di hadapan hukum (5:8), tidak merugikan diri sendiri dan orang lain (2: 279), melakukan kritik dan kontrol sosial (103: 1-3 dan 5: 78-79), menepati janji dan menjunjung tinggi kesepakatan (17:34), 
tolong-menolong untuk kebaikan (5: 2), yang kuat melindungi yang lemah (4: 75), musyawarah dalam urusan bersama (42:38), kesetaraan suami-isteri dalam keluarga (2: 187), saling melakukan yang makruf di antara suami-isteri (4: 19) (Mas'udi, 200: 31-33) dan lain-lain.

Pemahaman yang benar terhadap konsep qathî̀ dan zhannî mengenai nash-nash $\mathrm{Al}$-Qur'an dan hadis sangat membantu dalam memahami manakah nash yang merupakan pokok ajaran agama dan mana yang ornamen di mana inti ajarannya berada di balik ornamen tersebut. Ajaran qathî merupakan inti ajaran agama yang tidak berubah sepanjang masa, sedangkan ajaran zhannî merupakan ajaran yang mungkin penerapannya memerlukan beberapa penyesuaian dengan masa dan kondisi suatu masyarakat.

\section{Konsep Makkiyyah dan Madaniyyah}

Syari'ahIslam diturunkan kepada Nabi Muhammad secara bertahap selama kurang lebih 23 tahun, di Mekkah 13 tahun dan di Madinah 10 tahun. Syari'ah Muhammad ini berbeda dengan syari'ah para nabi sebelumnya yang diturunkan sekaligus. Turunnya Al-Qur'an secara

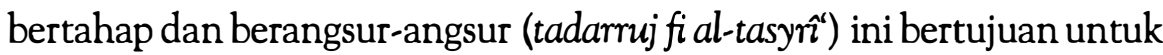
memantapkan dan meneguhkan hati, memudahkan dalam mentransformasikan syari'ah kepada para umatnya, dan memudahkan untuk menghafal dan memahaminya karena ayat-ayat Al-Qur'an diturunkan sehubungan dengan peristiwa-peristiwa, baik bersifat individual maupun sosial (al-Shâlih, 1993: 53-58).

Tahapan penurunan ayat tersebut melalui dua periodisasi besar, periode makkiyyah dan periode madaniyyah. Pemakanaan terhadap kedua periodisasi ini ada tiga pendapat. Pertama, pendapat yang didasarkan kepada tempat turun (makân al-nuzûl) yang berarti bahwa makkiyyah adalah ayat-ayat yang diturunkan di Mekkah dan sekitarnya (Mina, Arafah, Hudaibiyah dan lain sebagainya), baik ayat-ayat tersebut turun setelah hijrah atau sesudahnya. Sedangkan madaniyyah adalah ayat-ayat yang diturunkan di Madinah atau di sekitarnya (Badar, Uhud dan lain sebagainya), baik diturunkan setelah hijrah atau sesudahnya. Kedua, pendapat yang didasarkan pada orang yang diajak bicara (mukhâthabîn) 
yang berarti bahwa makkiyyah adalah ayat-ayat yang diturunkan berkenaan dengan orang-orang Mekkah, baik ayat-ayat tersebut diturunkan di Mekkah maupun di sekitarnya, baik setelah hijrah maupun sebelumnya. Ayat madaniyyah adalah ayat-ayat yang kandungannya tidak berkenaan dengan orang-orang Mekkah dan semisalnya seperti para penyembah berhala. Dan Ketiga, pendapat yang didasarkan kepada masa turun ayat (zamân al-nuzûl) mengartikan bahwa makkiyyah adalah ayatayat yang diturunkan sebelum hijrah Nabi ke Madinah, baik diturunkan di Mekkah atau di tempat-tempat lainnya. Sedangkan madaniyyah adalah ayat-ayat yang diturunkan setelah hijrah, baik diturunkan di Madinah, daerah-daerah lain atau dalam perjalanan (Ismấîl, 1985: 159 . 160). Periode makiyyah adalah ayat-ayat yang diturunkan sebelum hijrah Nabi ke Madinah, baik diturunkan di Mekkah atau di tempat-tempat lainnya. Sedangkan madaniyyah adalah ayat-ayat yang diturunkan setelah hijrah, baik diturunkan di Madinah, daerah-daerah lain atau dalam perjalanan.

Proses hijrah Rasulullah dari Mekkah ke Madinah bukan hanya merupakan langkah taktis, tetapi juga merupakan pertanda bagi perubahan isi pesan wahyu yang diturunkan. Pesan wahyu yang diturunkan di Mekkah lebih menekankan kepada prinsip toleransi dan egalitarianisme. Di Mekkah, Rasulullah mendakwahkan persamaan antara manusia di hadapan Allah dan menekankan sikap tanggung jawab individual yang harus diemban oleh semua orang, tanpa membedakan ras, jenis kelamin, dan agama (al-Na'im, 1987: 21).

Namun, ketika materi wahyu ini tidak diterima oleh orang-orang kafir Mekkah secara umum, bahkan para sahabat banyak yang disiksa, maka Rasulullah dan para sahabatnya terpaksa meninggalkan Mekkah untuk hijrah ke Madinah karena kondisi Mekkah sudah tidak kondusif lagi untuk mendakwahkan Islam. Berdasarkan pengalaman tentang kurang diterimanya materi ayat-ayat makkiyyaholeh orang-orang Mekkah, maka materi wahyu yang diturunkan di Madinah lebih disesuaikan dengan kondisi sosial, ekonomi, dan politik di Madinah pada waktu itu (al-Na'im, 1987: 21). Allah memberikan jawaban atas kebutuhan aktual dan potensial bagi masyarakat yang baru tumbuh dengan menurunkan 
wahyu yang tertuang dalam teks-teks Al-Qur'an dan hadis. Wahyu di Madinah inilah yang mengkonstruksi fikih pada masa-masa selanjutnya hingga masa sekarang.

Adanya dua periodisasi turunnya Syariat Islam ini yang di sisi lain juga mengandung perbedaan dalam materi ajaran memunculkan polemik konsep naskh, Abu Zahrah mempersyaratkan, di antaranya bahwa ayat yang menaskh harus ayat yang diturunkan belakangan daripada ayat yang dinaskh karena fungsi naskh adalah menghentikan hukum nas yang dinaskh. Akan tetapi di sisi lain Abu Zahrah mengatakan bahwa hukum yang tidak boleh dinaskh adalah hukum yang diakui oleh semua orang yang bernalar sehat akan kebaikannya yang harus diterima seperti: Iman Kepada Allah, beerbakti kepada orang tua, adil, dan yang diakui akan kejelekannya yang harus ditolak seperti: kezaliman dan kebohongan (Zahrah, T.th.: 191). Persyaratan ini membawa implikasi bahwa ayat makkiyyah dinaskh dengan ayat madaniyyah, tetapi implikasi ini tidak diterima oleh Khalid Masud yang mengatakan bahwa aturan-aturan yang bersifat parsial yang sebagian besar terdapat dalam ayat madaniyyah bisa dinaskh, sedangkan ayat-ayat makkiyyah yang mengandung prinsipprinsip universal dan fundamental tentang keadilan, kebaikan, kesabaran dan lain-lain tidak bisa dinaskh (Masud, 1984: 2005-2006).

\section{Pembacaaan Baru Terhadap Syarî'ah}

Syari'ah Islam adalah syari'ah penutup, diturunkan untuk seluruh manusia yang ada di muka bumi, baik yang berkulit hitam, merah, coklat, maupun sawo matang, diturunkan untuk semua bangsa, baik bangsa Arab, Amerika, maupun bangsa Indonesia, dan Syari'ah yang tidak hanya diperuntukkan bagi orang-orang yang hidup pada abad ketujuh, tetapi juga abad dua puluh satu dan seterusnya (Syahrûr, 2000: 22). Kondisi Syari'ah yang demikian menuntut umat Islam untuk selalu memperbaharui bacaan dan pemahamannya terhadap Syari'ah yang disesuaikan dengan kondisi dan perubahan masyarakat, termasuk masyarakat global.

Al-Qur'an merupakan pedoman dan ajaran yang berpengaruh besar bagi kehidupan masyarakat di dunia Islam. Oleh karena itu 
pencarian Islam harus dimulai dan bertitik tolak dari pemahaman terhadap kitab Allah dan dengan memahami secara benar proses turunnya Al-Qur'an. Dengan perangkat keilmuan dan teknologi yang lebih modern umat Islam sekarang memiliki kerangka pemahaman metodologis yang lebih baik dibandingkan dengan para pendahulunya (abad ke-7 M) dalam memahami pesan-pesan Allah (Al-Qur'an) yang disampaikan kepada Rasul-Nya.

Al-Qur'an tidak terpengaruh dengan waktu, yang terpengaruh dengan waktu adalah pemahaman terhadapnya. Pemahaman Nabi, para sahabat, dan para khalifah terhadap Al-Qur'an dipengaruhi oleh kondisi sosial masyarakat pada waktu itu. Oleh karena itu, ketika umat Islam membaca dan memahami Al-Qur'an harus memanfaatkan informasi ilmiah yang telah didapatkan dan disesuaikan dengan kemajuan dan perkembangan teknologi yang pesat pada akhir-akhir ini. Syahrûr menyarankan agar kita memahami Al-Qur'an, seakan-akan wahyu Allah baru diturunkan ke dunia kemarin dan Nabi baru saja meninggal dunia (Syahrûr, 1990: 41). Dengan demikian, nash-nash Al-Qur'an seakan-akan diturunkan berkenaan dengan permasalahan yang terjadi sekarang ini. Oleh karena itu untuk memahami nash Al-Qur'an, perlu menggunakan perangkat keilmuan dan teknologi yang berkembang saat ini, bukan berdasarkan informasi dari para ulama fikih (Syahrûr, 1990: 182) yang dalam memahami Al-Qur'an juga disesuaikan dengan kondisi keilmuan dan masyarakat pada waktu itu.

\section{Penutup}

SyariatIslam merupakan ketentuan-ketentuan Allah yang diperuntukkan untuk manusia di seluruh muka bumi, tanpa membedakan ras, suku, warna kulit, dan golongan. Syariat Islam juga diperuntukkan untuk semua masa setelah Muhammad, baik pada abad ketujuh maupun abad kedua puluh satu. Dengan berpatokan kepada semboyan "al-Islam shalih li kull zamân wa makân" (Islam senantiasa sesuai dengan perkembangan zaman dan tempat), maka pemahaman kita terhadap syariat senantiasa mengalami perubahan mengingat berubahnya kondisi sosial dan perangkat metodologis yang berupa perkembangan ilmu yang juga berubah. 


\section{DAFTAR PUSTAKA}

Cooper, John et. al., 2000. Islam and Modernity; Muslim Intelectual Response, New York: I.B. Tauris.

Departemen Agama R.I., 1973. Alkitab, Vol. 2, Jakarta: Lembaga Alkitab Indonesia.

Al-Fâsî,'Allâl, Maqâshid al-Syarî́ah al-Islâmiyyah wa Makârimuha, tt.:

Maktabah al-Wahdah al-Arabiyyah al-Dâr al-Baydhâ', tth.

Ismâ'îl, Sya'bân Muhammad, 1985. al-Tasyn̂̋' al-Islamî, Mashadiruh wa Athwaruh, Kairo: Maktabah al-Nahdhah al-Mishriyyah.

Khalâf, 'Abd al-Wahhâb, 1978. 'Ilm Ushûl al-Fiqh, Kuwait: Dâr al-Qalam. Manzhûr, Ibn, Lisan al-Arab, Jilid 8., Beirut: Dâr al-Shâdir, t.t.

Mas'udi, Masdar F., 2000. Islam dan Hak-hak Reproduksi Perempuan; Dialog Fiqih Pemberdayaan, Edisi Revisi, Bandung: Mizan.

Masud, Muhammad Khalid, 1984. Islamic Legal Philosophy, Islamabad Pakistan: Islamic Research Institute.

Al-Na'im, Abdullahi Ahmed, 1987. "Translator's Introduction" dalam Mahmoud Mohamed Taha, The Second Message of Islam, New York: Syracuse univesity Press.

Al-Qaradhâwî, Yûsuf, 2001. Madkhal li Dirasah al-Syari'ahal-Islamiyyah, Kairo: Maktabah Wahbah.

Qal'ajî, Muhammad Rawâs dan Hâmid Shâdiq Qunaybî, 1985. Mu'jam Lughah al-Fuqaha'; 'Arabî-Inklî̀î, Beirut: Dâr al-Nafâ'is.

Al-Shâlih, Shubhi, 1993. Membahas Ilmu-Ilmu al-Qur'an, ter. Tim Pustaka Firdaus, Jakarta: Pustaka Firdaus.

Sânû, Quthb Mushthafâ, 2000. Mu'jam Musthalahat Ushûll al-Figh 'ArabîInklîzî, Beirut: Dâr al-Fikr al-Mu'âshir.

Syahrûr, Muhammad, 1990. al-Kitâb wa al-Qur'an; Qira'ah Mu'âshirah, Damaskus: al-Ahâli li al-Thibâ'ah wa al-Nasyr wa al-Tauzî‘.

__ 2000. Nahw Ushûl al-Jadîdah li al-Fiqh al-Islamîi; Fiqh al-Mar'ah, Damaskus: al-Ahâli li al-Thibâ'ah wa al-Nashr wa al-Tauzî‘.

Sjadzali, Munawir, 1995. Kontekstualisasi Ajaran Islam, Jakarta: Paramadina. 
Taha, Mahmoud Mohamed, 1996. The Second Message of Islam, New York: Syracuse University Press.

Tibi, Bassam, 1991. Islam and The Cultural Accomodation of Social Change, ter Clare Krojzl, Oxford: Westview Press.

Wehr, Hans, 1976. Arabic-English Dictionary, A Dictionary of Modern Written Arabic ed. JM. Cowan, New York: Spoken Language Service.

Weiss, Bernard G., 1998. The Spirit of Islamic Law, Athens: The University of Georgia Press.

Zahrah, Muhammad Abû, Ushûl al-Fiqh, t.t.: Dâr al-Fikr al-'Arabî, t.t. 